\title{
The potential for production of high quality seed potatoes in Tierra del Fuego Island, Argentina
}

\author{
D.O. CALDIZ1 , O.H. CASO², G. VATER ${ }^{3}$ and L.V. FERNANDEZ1
}

I Instituto de Fisiología Vegetal. Facultad de Ciencias Agrarias y Forestales, Universidad Nacional de La Plata. CC 327. 1900 La Plata. Argentina

2 Centro de Ecofisiología Vegetal, Consejo Nacional de Investigaciones Científicas y Técnicas, Serrano 665, 1414 Capital Federal. Argentina

3 Centro Austral de Investigaciones Científicas, Consejo Nacional de Investigaciones Científicas y Técnicas. CC 92.9410 Ushuaia. Argentina

Accepted for publication: 7 December 1998

Additional keywords: cultivar, virus diseases, nematodes, ground cover, physiological age, seed production, Solanum tuberosum L.

\section{Summary}

In Argentina, different areas are suitable for seed potato production: however, each has particular problems, mainly related to different pest and diseases. Tierra del Fuego Island is well isolated from traditional potato growing areas. Therefore, it was tested for its potential for seed production.

The cultivars Achatt. Mailén INTA. Pampeana INTA and Spunta were grown in Río Grande. San Pablo and Ushuaia from 1991-1994. Nematode presence and aphid population dynamics were recorded. Average tuber yield ranged from 20.1-37.6 t ha-1. After three years PVY and PLRV remained low (0-1\% for different cultivars and locations). Moreover. seed tubers obtained were physiologically young. Long days. early frosts and strong winds may limit tuber vield in some years. The island can be considered as an ecological "safe haven" and is very suitable to obtain healthy and physiologically adequate seed potatoes.

\section{Introduction}

According to Mendiburu (1986), the history of the production of seed potatoes in Argentina can be divided into four periods: (1) beginning of crop production-1936. local seed production with local and foreign cultivars: (2) 1937-1955. seed imports only: (3) 1955-1984/85, use of both local and imported seeds: (4) 1984/85- present. self-sufficiency. Seed imports in period (1) were putatively needed because of "seed degeneration" of local cultivars Chaqueña and Blanca, associated with the incidence of virus diseases (Sívori, 1951), and also because of lack of interest of commercial growers (Anon., 1954). During period (2) mainly White Rose and Kathadin, imported from Canada, were used, while in period (3) both local (such as Huinkul MAG, Ballenera MAA, Sierra Volcán and Sierra Bachicha) and imported cultivars (such as Kennebec, Spunta and Jaerla) were used. Period (4) started as a result of the adoption of in vitro techniques, wide use of the ELISA test and production of basic seed in isolated areas (Escarrá. 1989).

Traditionally more than $50 \%$ of the potatoes of the country (seed, ware and processing) are grown in the southeast area of the Buenos Aires province (Fig. 1a, site 5), while potato seed tubers are also produced in several other areas as shown in 


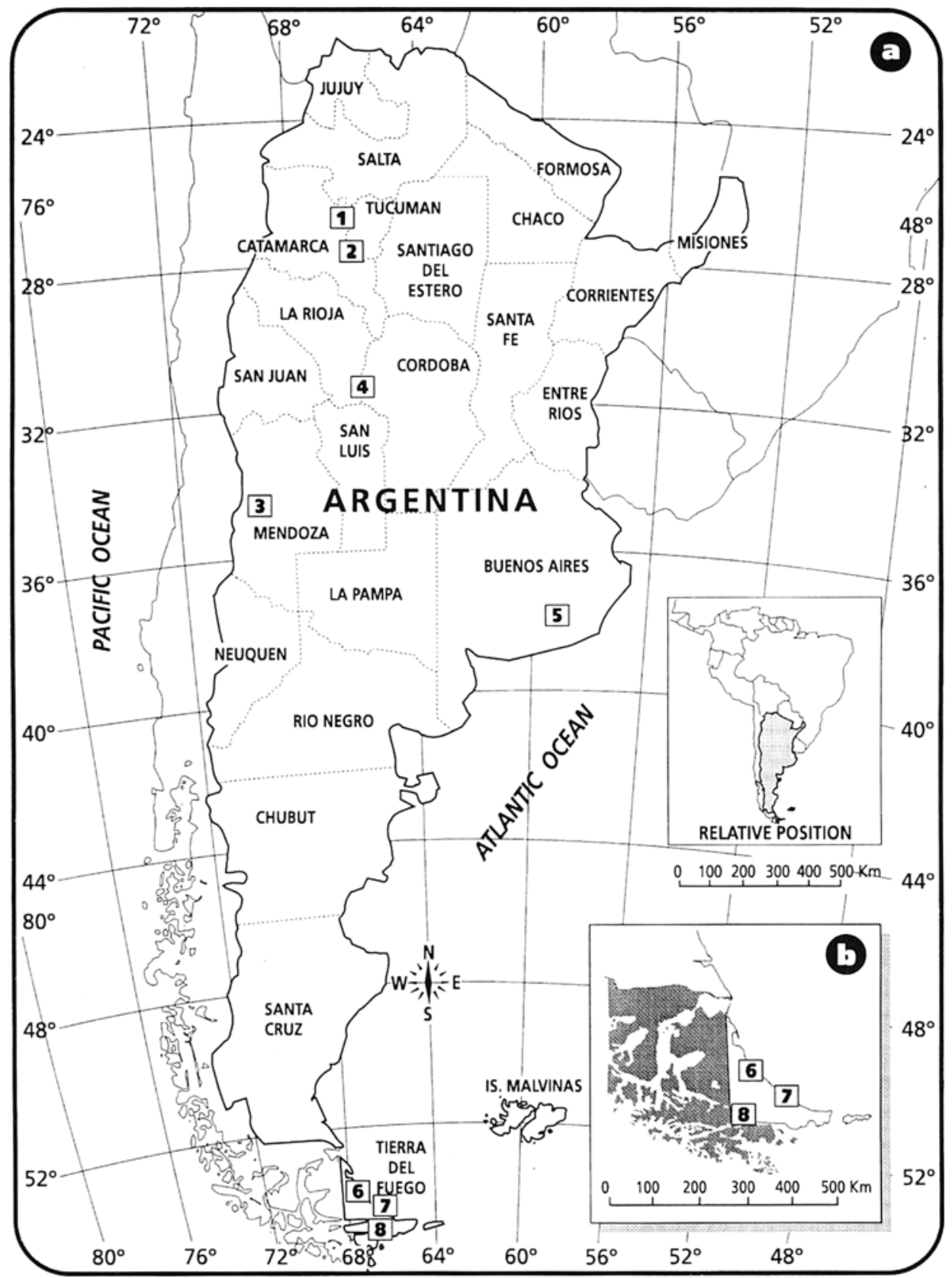

Fig. 1. Seed potato production zones in Argentina (a) and areas studied in Tierra del Fuego (b). References: (1) Tafí del Valle, Tucumán; (2) Las Estancias, Catamarca; (3) Malargüe, Mendoza; (4) Pampa de los Gigantes, Córdoba; (5) Southeast of Buenos Aires Province. In Tierra del Fuego: (6) Río Grande; (7) San Pablo and (8) Ushuaia. 
Fig. 1a, such as Tafí del Valle (1), Las Estancias (2), Malargüe (3) and Pampa de los Gigantes (4). Certain fields in these areas have particular problems, such as soil erosion (Orell, 1990) and presence of Nacobbus aberrans in Tafí del Valle (Costilla et al., 1978); presence of Meloidogyne spp. (Chaves, 1989) and aphids in the southeast of Buenos Aires; high levels of potato virus Y (PVYN) in Malargüe (Ferreyra, 1990; J. Ortego, personal communication, 1995) and difficult accessibility at Las Estancias (A. Santángelo, personal communication, 1989), which could also be an advantage regarding isolation. In all these areas, seed is produced during October-March (spring-summer period in the southern hemisphere), either on the mountains or in coastal areas (Haverkort \& Caldiz, 1994) and is delivered to be planted in the ware potato areas in February-March (late), May-June (early), July-August (mediumearly) and October-November (medium-late) crops, respectively. The combination of seed origin, environmental conditions and planting time means that in many cases the seed is too young or too old to achieve high yields. Detailed information about seed and ware potato in Argentina can be found elsewhere (Mendiburu, 1986; Haverkort \& Caldiz, 1994). New growing areas need to be identified to preserve self sufficiency in the production of basic seed and to improve yields of ware crops.

Tierra del Fuego is an island located in the most southern part of Argentina (52 $30^{\circ}$ to $55^{\prime} \mathrm{SL}$ ) and has only very limited means of access. This can contribute to an efficient control of seed movement. Following introductions from Europe or Chile, potatoes have been multiplied on the island for more than 30 years, in small family plots without being seriously infected with virus diseases. A report from Huarte \& Butzonich (1984) recognized the potential of the island for seed and ware production, but since then no attempts have been made to exploit this opportunity. Several factors, however, determine tuber yield there, such as long days during crop growth delaying tuber initiation, the occurrence of late and early frosts and the constant presence of strong winds in the northern part of the island.

In order to test the importance of these factors a series of field trials was carried out at three locations of the island during 1991-94. Trials included four cultivars, records of nematode presence, aphid population, incidence of virus diseases and assessments of tuber yield and physiological age of the seed produced. It is also proposed to consider this work as a case study to be applied for similar situations elsewhere in the world.

\section{Materials and methods}

\section{Agro-ecological conditions in Tierra del Fuego Island}

Tierra del Fuego Island has a characteristic oceanic cold climate and the temperature is controlled by cold oceanic currents and the ice masses from Antarctica. Mean temperatures of the coldest month are 0 to $-2{ }^{\circ} \mathrm{C}$ whereas the mean temperatures for the warmest month are $8-10^{\circ} \mathrm{C}$. Occidental winds are predominant and rainfall ranges from $300 \mathrm{~mm}$ in the northern part of the island to more than $1000 \mathrm{~mm}$ in the area of Cordillera de los Andes, running from northwest to southeast. The experiments were carried out at three different locations during the summer season 
of 1991/92, 1992/93 and 1993/94. These three locations, Río Grande (6), Cabo San Pablo (7) and Ushuaia (8) have different agro-ecological conditions (Fig. 1b).

Rio Grande. This location (referred to as RG) belongs to the Magallanic Steppe. It is an arid area with rainfall between $200-400 \mathrm{~mm}$ and strong occidental winds. The soils are Pachic crioborolls with loam texture, 4-6\% organic matter and low $\mathrm{pH}$ (Soil Survey Staff, 1992).

Cabo San Pablo and Ushuaia. Both locations belong to the Magallanic Deciduous Forest. This natural formation occupies the central and eastern part of the island and can be divided into two sub-areas. The northern part occupies the northwest of Cordillera de los Andes, with prevalence of the native tree Nothofagus antarctica, that spreads towards the steppe. Soils are Typic crioborolls, loamy, with up to $12 \%$ organic matter (Soil Survey Staff, 1992). "Estancia Inés", in Cabo San Pablo belongs to this environment (San Pablo, SP). The other sub-area is a typical forestry area, well represented in "Estancia Río Pipo", Ushuaia (USH). Soils are Typic criumbrepts with high clay content (Soil Survey Staff, 1992). To provide an indication of the climate for the region data from Ushuaia 1992/93 are shown (Fig. 2).

Experiments in Rio Grande and Ushuaia, 1991/92. Certified seed tubers produced during the season 1990/91 in the Balcarce area (Fig. 1a, site 5) of the medium early cultivars Achatt, Mailén INTA, Pampeana INTA and Spunta were pre-sprouted in diffuse light for one month before planting, at a temperature of $20-25{ }^{\circ} \mathrm{C}$ in a

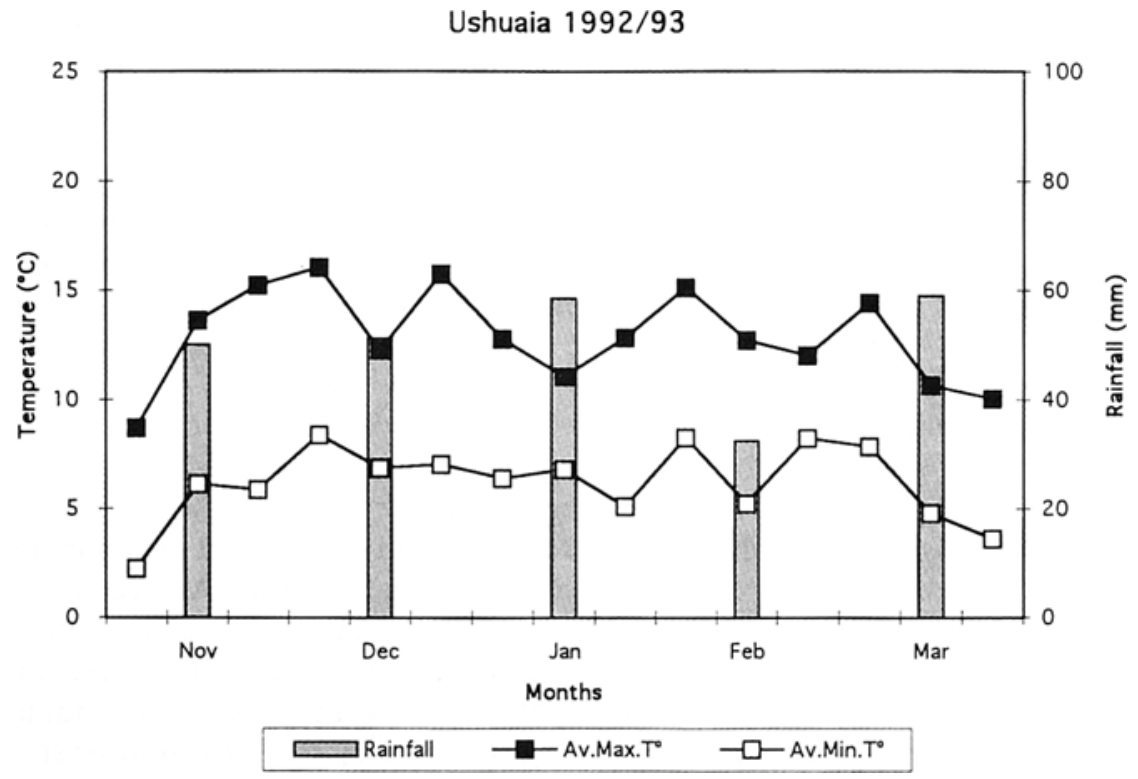

Fig. 2. Meteorological data for Ushuaia 1992/93. 
laboratory and at $10-15^{\circ} \mathrm{C}$ in a farm barn, for Ushuaia and Río Grande trials, respectively, in order to obtain 2-4 short $(<20 \mathrm{~mm})$ sprouts per tuber. Planting was done by hand on November 16 (Ushuaia) and 18 (Río Grande), 1991. Rows were 0.70 $\mathrm{m}$ apart and plant distance within the row was $0.30 \mathrm{~m}$. Plot size was $2.8 \times 12 \mathrm{~m}$ and experiments were laid down in a complete randomized block design with four replicates.

Experiments in Río Grande, San Pablo and Ushuaia in 1992/93. In this season the material produced in the island during 1991/92 was used. These tubers were stored at $2{ }^{\circ} \mathrm{C}$ in Ushuaia till one month before planting. Planting was carried out at three sites, Río Grande, San Pablo and Ushuaia with tubers pre-sprouted in diffuse light in farm barns at each of the three places, in similar plots to those used in 1991/92 with 6 rows. Seed lots were moved within the island to test possible cultivar $\times$ site interaction; henceforward, seed origin (year before or both years before) is shown within brackets after each cultivar name. The potatoes were planted at Río Grande, San Pablo and Ushuaia on November 2, 4 and 6, 1992, respectively.

Experiments in Rio Grande, San Pablo and Ushuaia in 1993/94. Planting was carried out with pre-sprouted tubers in plots of 6 rows, $20 \mathrm{~m}$ long. The potatoes were planted at Río Grande, San Pablo and Ushuaia on October 27, 29 and November 1, 1993, respectively.

\section{Crop management and assessments}

Cultivation, ground cover and tuber yield. All experiments were carried out in different fields of the same farms without irrigation. N-P-K (18-46-0), $150 \mathrm{~kg} \mathrm{ha}^{-1}$, was applied each year. $\mathrm{N}$ dose was kept low to reduce haulm growth, already enhanced by the long days. Weeds were controlled mechanically and/or chemically with metribuzin (1 $1 \mathrm{ha}^{-1}$; pre and post-emergence) and with pirifenop (4 $1 \mathrm{ha}^{-1}$; post-emergence). No other chemicals were applied. Between 45 and 50 days after planting the ridges were earthened up. Ground cover (GC) of the crop was regularly measured following the procedure proposed by CIP (Centro Internacional de la Papa, 1986). These measurements were used to calculate ground cover duration (GCD) by applying the formula proposed by Watson (1952) for leaf area duration, as presented in Hunt (1982):

$\mathrm{GCD}_{1-2}=\left(\mathrm{GC}_{1}+\mathrm{GC}_{2}\right)\left(\mathrm{T}_{2}-\mathrm{T}_{1}\right) \cdot 2^{-1}$

where: GC is ground cover and T time. GCD provides an estimate of the fraction of the incident radiation intercepted by the canopy (Burstall \& Harris, 1983).

Roguing was carried out twice during crop growth in each trial to eliminate virus infected plants. The two central rows of each plot were harvested to determine tuber yield and values were converted into $\mathrm{tha}^{-1}$. In each year harvests were carried out in late March and tubers were stored in underground structures or in a wooden barn till the following planting season. For each location and year, analysis of variance was carried out and means were separated by Tukey's test $(\mathrm{P}<0.05)$. 
Nematodes and virus detection. One month before planting, soil samples $(2-3 \mathrm{~kg}, 40$ sub-samples each) were taken for each field trial and location to determine the presence of nematodes. Samples were analyzed by two different government approved laboratories. Each sample was analyzed for the presence of filiform and globe-shaped nematodes following the flotation-centrifugation technique and the Fenwick technique modified by Oostenbrink (1960) as described by Doucet (1980).

After each harvest a sample of 100 tubers per cultivar and location was sent to the laboratories already mentioned in 1991/92 and 1993/94, respectively, and to the Institute of Plant Physiology and Pathology from Instituto Nacional de Tecnología Agropecuaria at Córdoba (1992/93) to determine the presence of PVY and PLRV in seed tubers by the ELISA test.

Aphid population. To study the aphid population in each trial, for each location and year, a Moericke trap (Hille Ris Lambers, 1980) was set up in the middle of each field. Due to the low temperature the material in the traps was kept in good condition for two weeks, which allowed trays to be checked at that frequency instead of every 3-7 days, as recommended normally. In the field, the trap content was filtered, collected and kept in alcohol $80 \%$ for identification. Aphid species were identified by the laboratories mentioned earlier and INTA Malargüe. In the figures only the population of Myzus persicae Sulzer is shown, while other aphids not frequently found in the traps are mentioned in the text.

Assessment of physiological age. After harvest of the 1992/93 and 1993/94 crops, the physiological age of the seed tubers was measured. The incubation period, time elapsed from sprouting until new tuber formation, was used as an indicator of physiological age (Claver, 1953). When using this value it must be noted that a longer time means a physiologically younger seed tuber. After harvest, a sample of 40 tubers was put in trays of $0.25 \times 0.50 \times 0.10 \mathrm{~m}$ filled with vermiculite. The incubation period was measured in a dark growth room at $17 \pm 1{ }^{\circ} \mathrm{C}$ and $90 \%$ relative humidity, following procedures described by Caldiz (1991). A randomized design with four replicates of 10 tubers for each cultivar and origin was used. An analysis of variance was carried out and means were separated by Tukey's test $(\mathrm{P}<0.05)$.

\section{Results and discussion}

Ground cover, ground cover duration and tuber yield. Due to the use of pre-sprouted seed tubers, crop emergence was always good, $95-98 \%$, for all cultivars, years and locations. Pre-sprouted seed promotes early growth of roots and sprouts, enhancing crop establishment (Headford, 1962); pre-sprouting is an important management factor because of the short growing season available. In Ushuaia 1993/94, Spunta lots of different origins differed in initial development, probably due to differences in physiological age at planting. These differences also affected early GC and tuber yield (Fig. 3 and Table 1 ).

In 1991/92 GC was higher in Spunta than in other cultivars, either grown in Río 

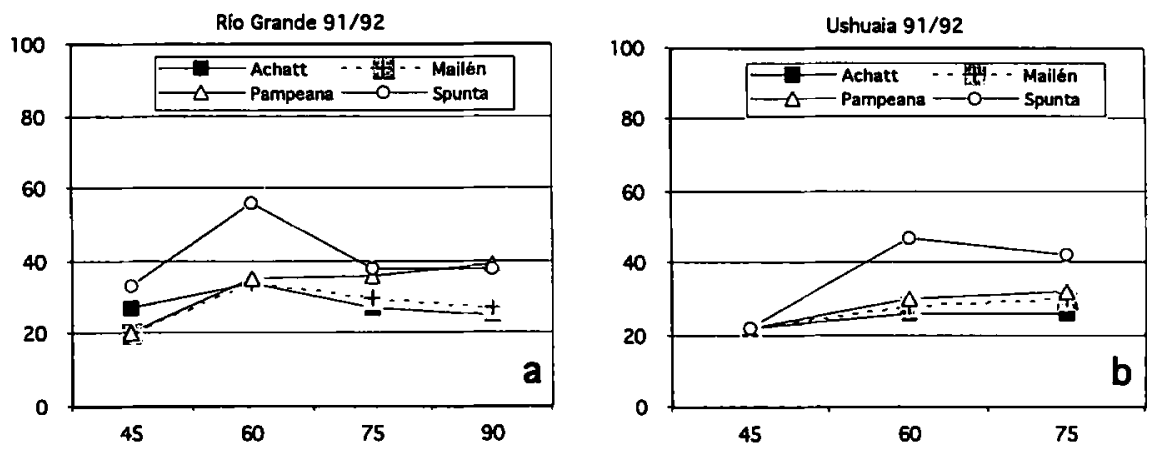

2
2
1
0
$>$
0
0
0
$=$
3
0
2
0
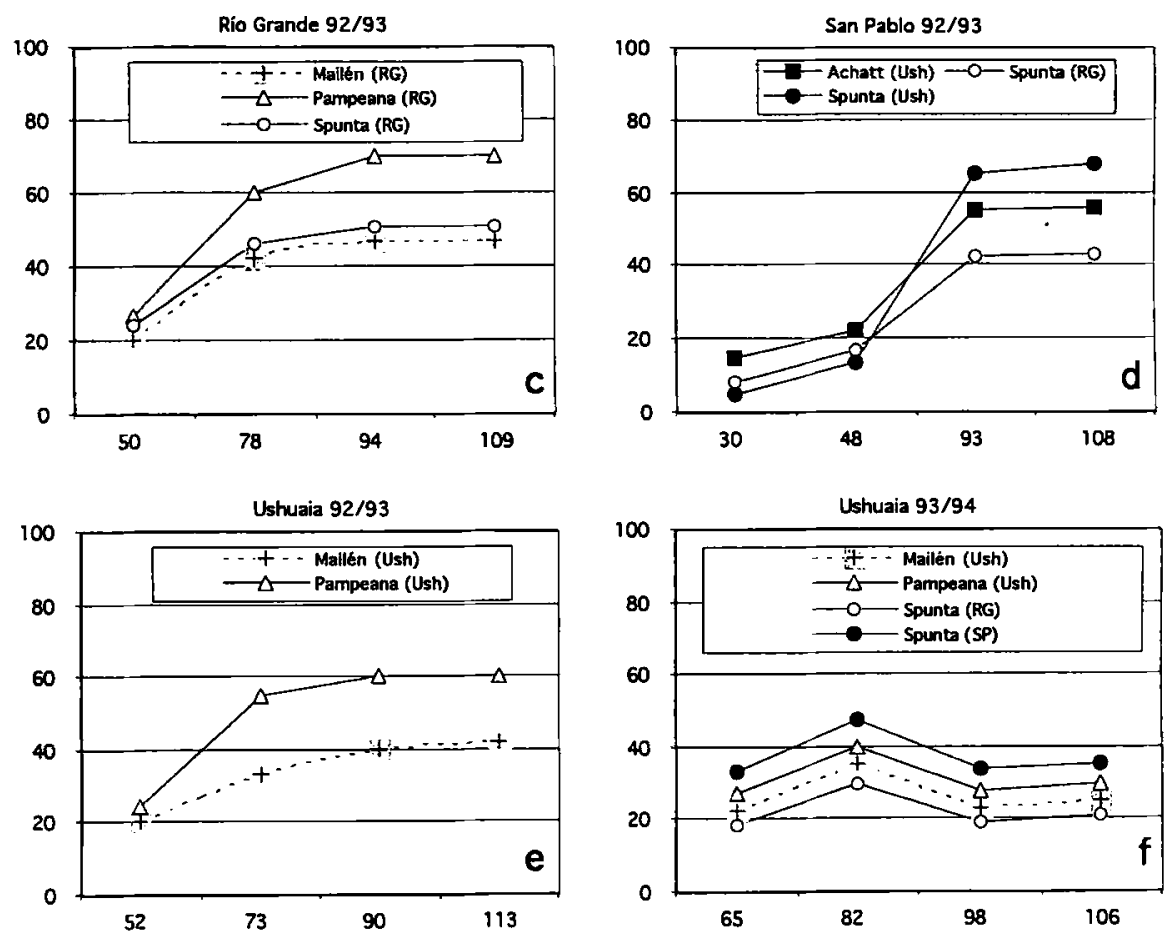

Days after planting

Fig. 3. Ground cover for all years, sites and cultivars.

References: Within brackets the production site in the previous year is shown. In Fig. 3f the origins are: Mailén (USH USH); Pampeana (USH USH); Spunta (RG RG) and Spunta (USH SP). 
Table 1. Tuber yield of different cultivars in each year and site in Tierra del Fuego, 1991-1994.

\begin{tabular}{|c|c|c|c|c|c|}
\hline $1991 / 92$ & $\begin{array}{l}\text { Tuber yield } \\
\left(\mathrm{tha}^{-1}\right)\end{array}$ & $1992 / 93$ & $\begin{array}{l}\text { Tuber yield } \\
\left(\mathrm{tha}^{-1}\right)\end{array}$ & $1993 / 94$ & $\begin{array}{l}\text { Tuber yield } \\
\left(t \mathrm{ha}^{-1}\right)\end{array}$ \\
\hline $\begin{array}{l}\text { Río Grande } \\
\text { Achatt } \\
\text { Mailén } \\
\text { Pampeana } \\
\text { Spunta }\end{array}$ & $\begin{array}{r}12.77 \mathrm{~b} \\
8.60 \mathrm{~b} \\
11.19 \mathrm{~b} \\
19.49 \mathrm{a}\end{array}$ & $\begin{array}{l}\text { Río Grande } \\
\text { Mailén (RG) } \\
\text { Pampeana (RG) } \\
\text { Spunta (RG) }\end{array}$ & $\begin{array}{l}24.00 \mathrm{~b} \\
33.42 \mathrm{a} \\
21.00 \mathrm{~b}\end{array}$ & $\begin{array}{l}\text { Rio Grande } \\
\text { Mailén (RG, RG) } \\
\text { Pampeana (RG, RG) } \\
\text { Spunta (RG, RG) }\end{array}$ & $\begin{array}{l}40.21 a \\
29.23 b \\
19.67 c\end{array}$ \\
\hline \multirow[t]{3}{*}{$\begin{array}{l}\text { Ushuaia } \\
\text { Achatt } \\
\text { Mailén } \\
\text { Pampeana } \\
\text { Spunta }\end{array}$} & $\begin{array}{r}8.71 \mathrm{~b} \\
8.84 \mathrm{~b} \\
7.35 \mathrm{~b} \\
17.56 \mathrm{a}\end{array}$ & $\begin{array}{l}\text { Ushuaia } \\
\text { Mailén (USH) } \\
\text { Pampeana (USH) }\end{array}$ & $\begin{array}{l}34.28 \mathrm{a} \\
32.57 \mathrm{a}\end{array}$ & $\begin{array}{l}\text { Ushuaia } \\
\text { Mailén (USH) } \\
\text { Pampeana (USH, USH) } \\
\text { Spunta (RG, RG) } \\
\text { Spunta (USH, SP) }\end{array}$ & $\begin{array}{l}16.80 \mathrm{~b} \\
17.79 \mathrm{~b} \\
16.95 \mathrm{~b} \\
32.40 \mathrm{a}\end{array}$ \\
\hline & & $\begin{array}{l}\text { San Pablo } \\
\text { Achatt (USH) } \\
\text { Spunta (RG) }\end{array}$ & $\begin{array}{l}19.71 \mathrm{c} \\
41.57 \mathrm{a}\end{array}$ & $\begin{array}{l}\text { San Pablo } \\
\text { Mailén (RG, RG) } \\
\text { Mailén (USH, USH) }\end{array}$ & $\begin{array}{l}22.80 \mathrm{~b} \\
15.42 \mathrm{c}\end{array}$ \\
\hline & & Spunta (USH) & $35.14 b$ & $\begin{array}{l}\text { Pampeana (RG, RG) } \\
\text { Pampeana (USH, USH) } \\
\text { Spunta (RG, SP) }\end{array}$ & $\begin{array}{l}23.60 \mathrm{~b} \\
17.10 \mathrm{c} \\
36.00 \mathrm{a}\end{array}$ \\
\hline
\end{tabular}

Means followed by the same letter within each year and site do not differ significantly $(\mathrm{P}<$ 0.05 ). Between brackets the origin of the seed in the previous crop (RG): Río Grande; (SP): San Pablo, and (USH): Ushuaia.

Grande or Ushuaia (Fig. 3a,b). No differences were found between other cultivars; although at Río Grande, Pampeana reached, on 75 days after planting, the GC of Spunta (Fig. 3a). In Ushuaia early frosts in mid January killed the foliage.

In 1992/93 for Río Grande and Ushuaia, Pampeana had a higher GC than Mailén and Spunta or Mailén, respectively (Fig. 3c,e). In San Pablo, both Spunta (RG) and Spunta (USH) had a higher GC than Achatt (USH), that only reached $40 \%$ of ground cover (Fig. 3d). In this season frosts were delayed until the end of February resulting in a long growing season at all locations (Fig. 3 c-d).

In 1993/94 for Río Grande, the maximum GC was 42, 37 and $30 \%$ for Mailén (RG, RG), Pampeana (RG, RG) and Spunta (RG, RG) (data not shown). For San Pablo maximum values were 42 and $30 \%$ for Pampeana (RG, RG) and Pampeana (USH, USH), 33 and $27 \%$ for Mailén (RG, RG) and Mailén (USH, USH) and $32 \%$ for Spunta (RG, SP), respectively. In Ushuaia (Fig. 3f) a large difference in GC occurred between Spunta (RG, RG) and Spunta (USH, SP) that could be responsible for the considerable differences in tuber yield between these seed lots (Table 1). Low GC values achieved in all trials can be attributed, among other factors, to the low N-rate applied to counteract the effect of long days.

In potatoes, as in other crops, the production of dry matter under different environments is determined by the amount of intercepted radiation (Allen \& Scott, 1980; Haverkort \& Harris, 1986; Manrique et al., 1991). On the island, global 


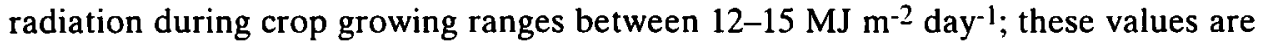
relatively low considering the 18 hours daylength. GCD differed between cultivars and years (Fig. 4). GCD values were lower than those obtained for the same cultivars under temperate conditions (D.O. Caldiz \& L.V. Fernández, unpublished). Low GCD values were due to low temperatures and early frosts that reduced and shortened leaf growth, respectively. However, tuber yield was closely related to GCD ( $r=0.74$, Fig. 4). Tuber yield during 1991/92 was the lowest one (Table 1), mainly due to the early frosts in February which abruptly interrupted foliage growth, reducing GC, GCD and shortened tuber growth period to 25 or 35 days for Ushuaia and Rio Grande, respectively (Figs. 3a-b and 4).

For the 1991/92 season at both sites, Spunta gave the highest yields, 17.6 and $19.5 \mathrm{t}$ $\mathrm{ha}^{-1}$ for Ushuaia and Rio Grande, respectively; whereas the other cultivars showed no differences. Tuber yields were much higher in the $1992 / 93$ season, mainly due to higher temperatures, both in Ushuaia and Rio Grande which allowed a greater GCD (Fig. 2). Moreover, the early planting, 15-20 days earlier than in 1991/92 season, contributed to early GC. In Río Grande, tuber yield was higher in Pampeana (RG) than in the other cultivars, whereas no differences were found between Mailén (RG) and Spunta (RG). In this last case, the crop was severely affected by strong winds. In San Pablo, Spunta (RG) produced the highest yields, with differences between

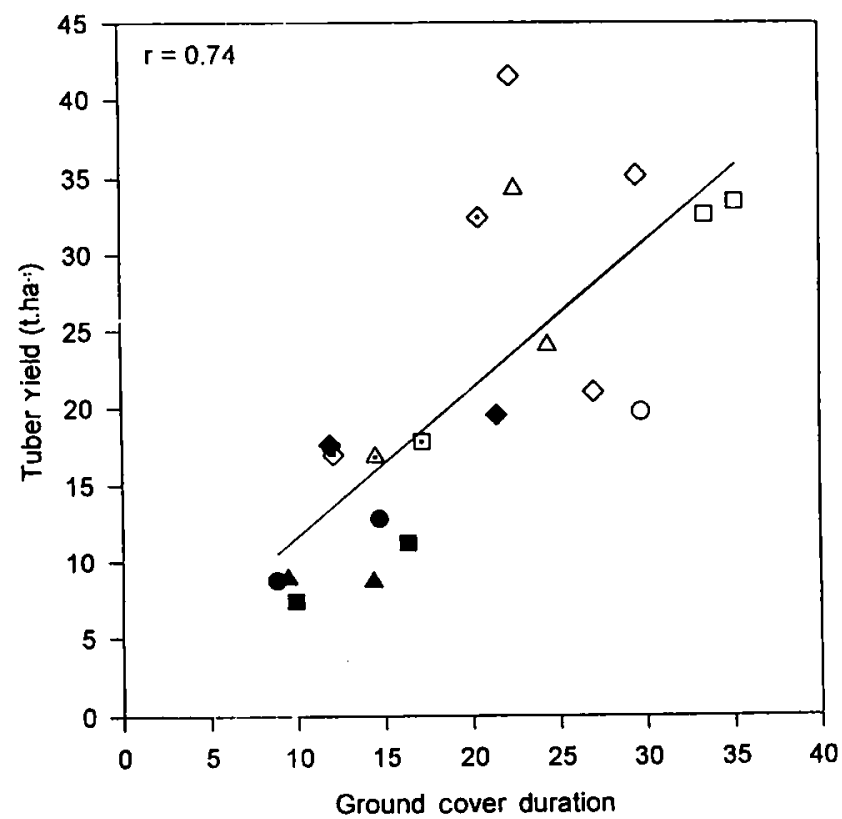

Fig. 4. Relationship between GCD and tuber yield for different cultivars and seasons in the period 1991-1994.

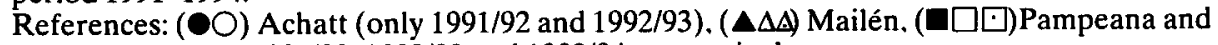
$(\diamond \diamond \odot)$ Spunta, for $1991 / 92,1992 / 93$ and $1993 / 94$, respectively. 
origins, probably due to the different physiological stage of the seed tubers. Tuber yield in Achatt (USH) was significantly lower than Spunta. In Ushuaia, no differences were observed between cultivars (Table 1).

Due to the low yields of Achatt in 1991/92 and 1992/93 this cultivar was not planted in the following crop. In 1993/94 for Río Grande, tuber yield was significantly higher in Mailén (RG, RG) followed by Pampeana (RG, RG) and Spunta (RG, RG). As already identified, the GC was an important physiological yield determinant. A similar situation was found in San Pablo, but in this site yields were higher in Spunta (RG, SP), and origin differences were registered between Mailén (RG, RG), Pampeana (RG, RG) and Mailén (USH, USH), Pampeana (USH, USH), respectively. In Ushuaia, no differences were observed between Mailén (USH. USH) and Pampeana (USH, USH) cultivars, while for Spunta (RG, RG) and (USH. SP), important differences between origins were observed which could be attributed to differences in physiological age, due to the different storage systems used for each seed origin, and differences in GCD (Fig. 4).

Nematodes. The soil samples analyzed each year for each site showed no plant pathogenic nematodes. Although the environment and soils where the trials were conducted are representative for those in different areas of the island, it is recommended to take soil samples to detect the presence of nematodes before a new crop is planted.

Aphid population and virus diseases. Aphids play a key role in the epidemics of PVY and PLRV, because aphid transmission is the only relevant way of virus dissemination from plant to plant in the field (Beemster \& de Bokx, 1987). In Figure 5a-c Myzus persicae population for each site and season is presented. The highest number of aphids per trap, 8 and 16, were registered 110 and 91 days after planting in Río Grande 1991/92 and Ushuaia 1993/94, respectively (Fig. 5a, c). In 1992/93 the lowest aphid population for each site was registered and in San Pablo a single aphid was counted late in the season, 140 days after planting when the foliage was already killed by frosts (Fig. 5b). In 1993/94 the highest aphid population was registered for Ushuaia, with more than 5 aphids per trap on five occasions. In Río Grande and San Pablo the population was very low. These values are lower than those recently reported for Tafí del Valle (Fig. 1a, site 1), a seed potato producing region in the Aconquija mountains at $2220 \mathrm{~m}$ above sea level. Zamudio et al. (1996) reported for the Tafí region in the growing period September-March 1991/92-1995/96 a minimum and maximum counting of $M$. persicae of 10 (November, 1993) and 130 (February 1995), respectively, with an average value of more than 30 aphids month ${ }^{-1}$.

Aphid species found during these trials were Brachycaudus helichrysi, B. rumexicolens, Cavariella aegopdii, Lipaphis erysimi, Macrosiphum euphorbiae, Myzus persicae, Pemphigus spp. and Rhopalosiphum ninphae. Of these only $B$. rumexicolens and $R$. ninphae are not clearly involved in potato virus transmission (J. Ortego, personal communication, 1994). M. persicae was the most abundant among these species. Like in some seed growing upland districts of Scotland and Wales 
$1991 / 92$
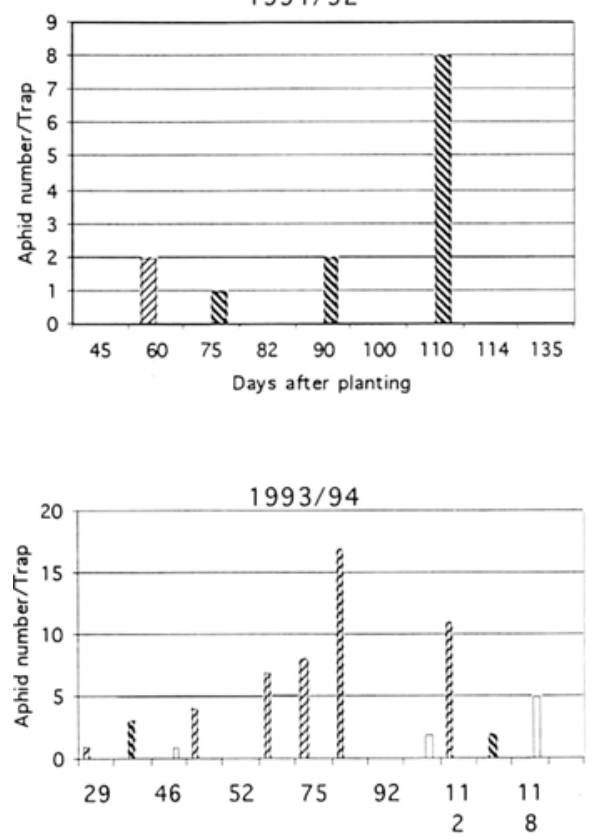

Days after planting
$1992 / 93$

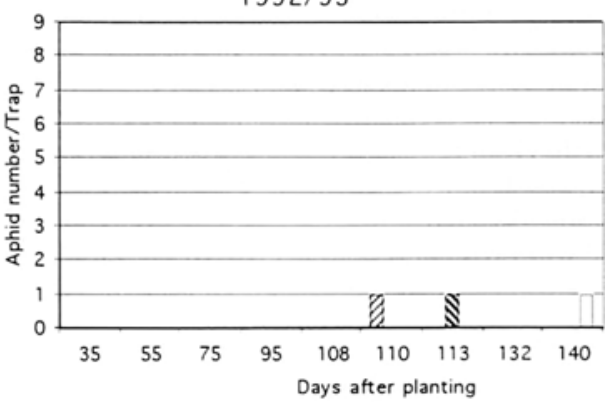

QUshuaia $\quad$ SRio Grande $\quad$ San Pablo

Fig. 5. Myzus persicae population dynamics for all years and sites.

(Ministry of Agriculture, Fisheries and Food, 1979), the growing season in Tierra del Fuego is too cool and windy for rapid multiplication of aphids or aphid movement, reducing virus transmission to a minimum. This is confirmed by the post-harvest tuber tests on the presence of PVY and PLRV (Table 2). The certified seed produced in the traditional seed growing area of the country showed an initial high value of PVYN in Mailén for Ushuaia and Río Grande, of $11 \%$ and $6 \%$, respectively, whereas $5 \%$ PVYN occurred in Spunta, in Río Grande, after the 1991/92 growing season. Due to roguing, carried out in each year, in the $1992 / 93$ season these values were reduced to $0 \%$. For the season 1993/94 the values for PVY and PLRV ranged from $0-1 \%$ (Table 2). Windy and cold weather resulted in low aphid populations and in addition to meteorological effects on aphid flights, these regions tend to have low aphid abundance, presumably because they are avoided by winged migrants (Nemecek, 1993). These results showed that the island has a low degeneration rate and may allow the multiplication of basic seed for several generations without increasing virus incidence.

Physiological age of the seed tubers. After the 1992/93 growing season no large differences in physiological age at harvest were registered between cultivars and 
Table 2. PVY and PLRV percentage for different cultivars for each year and site in Tierra del Fuego, 1991- 1994.

\begin{tabular}{|c|c|c|c|c|c|}
\hline $1991 / 92$ & Virus \% & $1992 / 93$ & Virus $\%$ & $1993 / 94$ & Virus \% \\
\hline $\begin{array}{l}\text { Río Grande } \\
\text { Achatt } \\
\text { Mailén } \\
\text { Pampeana } \\
\text { Spunta }\end{array}$ & $\begin{array}{l}0 \\
6 \mathrm{PVY} \\
0 \\
5 \mathrm{PVY}\end{array}$ & $\begin{array}{l}\text { Rio Grande } \\
\text { Mailén (RG) } \\
\text { Pampeana (RG) } \\
\text { Spunta (RG) }\end{array}$ & $\begin{array}{l}0 \\
0 \\
0\end{array}$ & $\begin{array}{l}\text { Río Grande } \\
\text { Mailén (RG, RG) } \\
\text { Pampeana (RG, RG) } \\
\text { Spunta (RG, RG) }\end{array}$ & $\begin{array}{l}1 \text { PLRV } \\
0 \\
0\end{array}$ \\
\hline \multirow[t]{2}{*}{$\begin{array}{l}\text { Ushuaia } \\
\text { Achatt } \\
\text { Mailén } \\
\text { Pampeana } \\
\text { Spunta }\end{array}$} & $\begin{array}{l}0 \\
13(*) \\
0 \\
0\end{array}$ & $\begin{array}{l}\text { Ushuaia } \\
\text { Mailén (USH) } \\
\text { Pampeana (USH) }\end{array}$ & $\begin{array}{l}0 \\
0\end{array}$ & $\begin{array}{l}\text { Ushuaia } \\
\text { Mailén (USH) } \\
\text { Pampeana (USH. USH) } \\
\text { Spunta (RG, RG) } \\
\text { Spunta (USH, SP) }\end{array}$ & $\begin{array}{l}0 \\
0 \\
1 \mathrm{PVY} \\
0\end{array}$ \\
\hline & & $\begin{array}{l}\text { San Pablo } \\
\text { Achatt (USH) } \\
\text { Spunta (RG) } \\
\text { Spunta (USH) }\end{array}$ & $\begin{array}{l}0 \\
0 \\
0\end{array}$ & $\begin{array}{l}\text { San Pablo } \\
\text { Mailén (RG, RG) } \\
\text { Mailén (USH. USH) } \\
\text { Pampeana (RG, RG) } \\
\text { Pampeana (USH, USH) } \\
\text { Spunta (RG, SP) }\end{array}$ & $\begin{array}{l}0 \\
0 \\
1 \text { PLRV } \\
0 \\
0\end{array}$ \\
\hline
\end{tabular}

The virus type, PVY or PLRV, is indicated after each figure.

(*), $11 \%$ PVY and $2 \%$ PLRV.

sites. As physiological age was measured only to test the effect of the previous growing conditions, and not the effect of storage conditions it is possible that differences in physiological age at planting are responsible for the differences in early GC and tuber yield between Spunta (RG, RG) and Spunta (USH, SP) grown in Ushuaia in 1993/94.

In contrast to $1992 / 93$ in 1993/94 some differences between cultivars and sites were registered. All Pampeana lots had an advanced physiological age when compared with Mailén or Spunta from different origins (Table 3). When the physiological age of Spunta seed tubers grown at Tierra del Fuego was compared with that of seed tubers grown in the south east of Buenos Aires Province (Caldiz \& Fernández, 1995), it resulted in younger seed in two out of three cases. Moreover, when compared with average values for Spunta seed produced over several years in the southeast region (Caldiz, 1994) the tubers produced in the island were physiologically younger (Table 3 ). This can be an advantage for use of these tubers in other regions with long growing seasons, to increase the yield potential of the crop.

Seed yields, on average for the three seasons, and for each cultivar, were acceptable (20.1 and $37.6 \mathrm{t} \mathrm{ha}^{-1}$, for Pampeana (USH) and Spunta (SP), respectively), and, the seed was very healthy concerning virus freedom. Moreover no fungal or bacterial diseases were present. Such conditions, that allow seed multiplication for several generations without enhancing virus transmission make the island a "safe heaven", suitable for, either basic seed multiplication or breeding programmes to carry out 
Table 3. Physiological age of seed tubers, measured by the length of the incubation period, immediately after harvest for different years and sites in Tierra del Fuego, 1991-1994.

\begin{tabular}{|c|c|c|c|}
\hline $1992 / 93$ & $\begin{array}{l}\text { Incubation period } \\
\text { (in days) }\end{array}$ & $1993 / 94$ & $\begin{array}{l}\text { Incubation period } \\
\text { (in days) }\end{array}$ \\
\hline $\begin{array}{l}\text { Río Grande } \\
\text { Mailén (RG) } \\
\text { Pampeana (RG) } \\
\text { Spunta (RG) }\end{array}$ & $\begin{array}{l}113 a \\
121 a \\
120 a\end{array}$ & $\begin{array}{l}\text { Río Grande } \\
\text { Mailén (RG, RG) } \\
\text { Pampeana (RG. RG) } \\
\text { Spunta (RG, RG) }\end{array}$ & $\begin{array}{r}112 \mathrm{a} \\
90 \mathrm{~b} \\
115 \mathrm{a}\end{array}$ \\
\hline $\begin{array}{l}\text { Ushuaia } \\
\text { Mailén (USH) } \\
\text { Pampeana (USH) }\end{array}$ & $\begin{array}{l}106 a \\
115 a\end{array}$ & $\begin{array}{l}\text { Ushuaia } \\
\text { Mailén (USH, USH) } \\
\text { Pampeana (USH. USH) } \\
\text { Spunta (RG, RG) } \\
\text { Spunta (USH, SP) }\end{array}$ & $\begin{array}{r}110 \mathrm{a} \\
93 \mathrm{~b} \\
115 \mathrm{a} \\
116 \mathrm{a}\end{array}$ \\
\hline $\begin{array}{l}\text { San Pablo } \\
\text { Spunta (RG) } \\
\text { Spunta (USH) }\end{array}$ & $\begin{array}{l}114 a \\
122 a\end{array}$ & $\begin{array}{l}\text { San Pablo } \\
\text { Mailén (RG, RG) } \\
\text { Mailén (USH. USH) } \\
\text { Pampeana (RG. RG) } \\
\text { Pampeana (USH, USH) } \\
\text { Spunta (RG. SP) }\end{array}$ & $\begin{array}{r}116 a \\
118 \mathrm{a} \\
88 \mathrm{~b} \\
75 \mathrm{c} \\
116 \mathrm{a}\end{array}$ \\
\hline
\end{tabular}

Means followed by the same letter, within each year, do not differ significantly $(P<0.05)$.

initial multiplications of new cultivars. In other areas such as the southeast of the Buenos Aires province an average of 5-15\% PVY has been found in the basic seed (M. Panelo, personal communication, 1998), while data for Malargüe showed that with an initial level of $5 \% \mathrm{PVY}^{\mathrm{N}}$ virus infection had increased to $30 \%$ (Ortego, 1995). Hence, the development of the island as a seed production area will contribute to the self-sufficiency policy started in 1984/85. The local and national authorities should establish strict regulations to preserve this unique situation and should support local farmers to improve crop management and technology to increase seed yield.

Moreover, based on these results it is concluded that this interesting case study can be relevant when the potential for seed potato production elsewhere in the world must be analyzed.

\section{Acknowledgments}

Research developed with a grant (PID) from the National Research Council (CONICET) and published with financial support from the National Agency for Scientific and Technological Research (SECyT, BID 802 OC/AR PID: 665). Argentina. The authors wish to thank Mr L. Preto, Ea. Río Pipo; Mr P. Suárez, Ea. María Behety and Mrs Solange Bilbao from Ea. Inés for their cooperation during the field trials. The field work done by Jorge Oyola and Luis Pinedo and transportation provided by Centro Austral de Investigaciones Científicas are greatly recognized. The cooperation of Diagnósticos Vegetales, Mar del Plata; Fitolabor, Miramar; 
Instituto de Fisiología y Fitopatología Vegetal, INTA Córdoba and Ing. Agr. J. Ortego, INTA Malargüe, with nematodes and virus analyisis and aphid identification is gratefully acknowledged. Thanks are due to Dr P.C. Struik. Wageningen Agricultural University and Dr A.J. Haverkort, AB-DLO, Wageningen, for critical reading of the manuscript and valuable comments. Suggestions from the Processing editor, Ir C.D. van Loon, are highly recognized.

\section{References}

Allen, E.J. \& R.K. Scott, 1980. An analysis of growth of the potato crop. Journal of Agricultural Sciences, Cambridge 94: 583-606.

Anonymous, 1954. La papa en el sudeste de la provincia de Buenos Aires. Cámara de Productores y Acopiadores de Papa, Balcarce, Argentina, 144 pp.

Beemster, A.B.R. \& J.A. de Bokx, 1987. Survey of properties and symptoms. In: J.A. de Bokx \& J.P.H. van der Want (Eds), Viruses of potatoes and seed-potato production, 2nd ed. Pudoc, Wageningen, pp. 84-116.

Burstal, L. \& P.M. Harris, 1983. The estimation of percentage light interception from leaf area index and percentage ground cover in potatoes. Journal of Agricultural Sciences, Cambridge 100: 241-244.

Caldiz, D.O., 1991. Influence of origin and storage system on physiological age. crop growth and tuber yield of seed potato (Solanum tuberosum L.). Indian Journal of Agricultural Research 61: 1-6.

Caldiz, D.O., 1994. Genetic improvement and associated physiological changes in the potato. In: G.A. Slafer (Ed.), Genetic Improvement of Field Crops. Marcel Dekker, Inc., New York, pp. 361-411.

Caldiz, D.O. \& L.V. Fernández, 1995. Edad fisiológica de los tubérculos de papa producidos en la Argentina y sus implicancias para el cultivo posterior. I Seminario Latinoamericano da Cultura da Batata, Cámara Latinoamericana do Paraná, Curitiba, Brasil, 7-11 March 1995.

Centro Internacional de la Papa, 1986. Un método sencillo para determinar la cobertura foliar. Circular CIP 14: 6-8.

Costilla, M.A., S. González de Ojeda \& T. Hasselrot de Gómez, 1978. El falso nematode del nudo Nacobbus aberrans en cultivo de papa en Tucumán. Actas III Jornadas Fitosanitarias Argentinas, San Miguel de Tucumán, pp. 323-340.

Chaves, E., 1989. Distribución de Meloidogyne spp. en la provincia de Buenos Aires. Actas XIV Reunión de la Asociación Latinoamericana de la Papa, Mar del Plata, pp. 39.

Claver, F.K., 1953. Factores que influyen en la incubación de la papa. Turrialba 3: 32-34.

Doucet, M.E., 1980. Técnicas básicas en nematología del suelo. IDIA, Argentina 388: 34-43.

Escarrá, A.M., 1989. Etapa de consolidación del abastecimiento. Hacia la exportación de semilla? Enfoques del Sudeste 51: 9-10 \& 13.

Ferreyra, R.E., 1990. Producción de semilla en Malargüe, Mendoza. Actas Jornada de Actualización Técnica: Papa. Asociación Ingenieros Agrónomos Balcarce - Agencia de Extensión INTA Balcarce, Balcarce, pp. 11-13.

Haverkort, A.J. \& P.M. Harris, 1986. Conversion coefficients between intercepted solar radiation and tuber yields of potato crops under tropical highland conditions. Potato Research 29: 529-533.

Haverkort, A.J. \& D.O. Caldiz, 1994. Aardappelproduktie in Argentinië. Aardappelwereld Magazine 48: 18-20.

Headford, D.W.R., 1962. Sprout development and subsequent plant growth. European Potato Journal 5: 14-22.

Hille Ris Lambers, D., 1980. Pulgones: sus ciclos biológicos y su papel como vectores de virus. In: J.A. de Bokx (Ed.), Virosis de la papa y de la semilla de papa. Editorial Hemisferio Sur S.A., Buenos Aires, pp. 25-53. 
Huarte, M. \& I.P. Butzonich, 1984. Estudio de factibilidad para la producción de semillas de alta sanidad en Tierra del Fuego. Informe Técnico INTA Balcarce, $4 \mathrm{pp}$.

Hunt, R., 1982. Plant growth curves. Edward Arnold Publishers, London, 248 pp.

Manrique, L.A., J.R. Kiniry, T. Hodges \& D.S. Axness, 1991. Dry matter production and radiation interception of potato. Crop Science 31: 1044-1049.

Mendiburu, A.O., 1986. Antecedentes de la producción de semilla en la Argentina. Reunión Técnica en Producción de Semilla Básica. Chacra Experimental de Miramar, Noviembre de 1986.

Ministry of Agriculture, Fisheries and Food, 1979. Potato virus diseases. Leaflet 139. Ministry of Agriculture, Fisheries and Food, Edinburgh. $8 \mathrm{pp}$.

Nemecek. T.. 1993. The role of aphid behaviour in the epidemiology of Potato Virus Y: a simulation study. PhD thesis. Swiss Federal Institute of Technology, ETH Zürich, $232 \mathrm{pp}$.

Oostenbrink, M., 1960. Estimating nematode populations by some select methods. In: J.N. Sasser \& W.R. Jenkins (Eds.), Nematology. University NC. Chapel Hill. pp. 85-102.

Orell, R., 1990. Papa semilla en Tafí del Valle. Actas Jornada de Actualización Técnica: Papa. Asociación Ingenieros Agrónomos Balcarce - Agencia de Extensión INTA Balcarce. Balcarce. pp. 5-10.

Ortego. J., 1995. Evolución de la infección con PVYN en papa en relación al grado de infección inicial y la actividad de los vectores. XVII Reunión de la Asociación Latinoamericana de la Papa. Mérida, Venezuela, 9-15 July, 1995.

Sívori. E.M., 1951. La degeneración de la papa. Ciencia e Investigación 7: 291-302.

Soil Survey Staff. 1992. Keys to soil taxonomy, 5th Edition. SMSS Technical Monograph $\mathrm{N}^{\circ} 19$. Blacksburg. Virginia, Pocahontas Press Inc.. $556 \mathrm{pp}$.

Watson, D.J.. 1952. The physiological basis of variation in yield. Advances in Agronomy 4: $101-145$.

Zamudio. N.. N.O. de Martínez \& R. Lobo. 1996. Uso de agroquímicos para control de áfidos en Tafí del Valle. Acciones tendientes a su racionalización. Avance Agroindustrial 17: 36-38. 